\title{
Pemahaman Pesan Moral pada Cerita Pendek melalui Storytelling di TPA Al-Ikhlas
}

\author{
Diyah Iis Andriani ${ }^{1}$, Selviana Teras Widy Rahayu ${ }^{2}$, Prichatin $^{3}$ \\ Universitas Pamulang ${ }^{123}$ \\ Korespondensi: dosen00605@unpam.ac.id'1,dosen02107@unpam.ac.id², \\ dosen00538@unpam.ac.id ${ }^{3}$
}

\begin{abstract}
Children's character must be shaped because it does not appear on its own. Apart from parents, schools, environment, and government, TPA (Taman Pendidikan Al-Qur'an) plays a strategic role to support children's character education. TPA Al-Ikhlas is one of the Islamic religious education institutions in the South Tangerang which is expected to be able to produce people who always strive to perfect their faith, piety and religious morals from an early age. However, there are several obstacles faced by students, namely, a lack of understanding of the importance of character building from an early age and difficulties in learning English which are caused by environmental factors and parents' backgrounds. Therefore, our Community Service Team (PkM) stepped in and offered a solution to the problem in the form of teaching using the storytelling method with pictorial story books and roll puppets. The moral messages obtained including being more confident, not being picky in making friends, not judging friends, being kind and friendly, and so on. Moral messages conveyed through attractive teaching media are able to provide maximum character education for children. Further, students can learn English together while increasing understanding of the moral messages in the story with more fun. In conclusion, this PkM activity using storytelling aims to shape children's character, provide moral messages and advice, entertain, and motivate children to speak English.
\end{abstract}

Keywords: character building, moral messages, storytelling

\begin{abstract}
Abstrak
Karakter seorang anak harus dibentuk karena tidak muncul dengan sendirinya. Selain orang tua, sekolah, lingkungan, dan pemerintah, TPA (Taman Pendidikan Al-Qur'an) memiliki peran strategis untuk mendukung pendidikan karakter anak. TPA Al-Ikhlas merupakan salah satu lembaga pendidikan agama Islam di daerah Tangerang Selatan yang diharapkan mampu menghasilkan manusia yang selalu berupaya menyempurnakan iman, takwa, dan berakhlak mulia agama sejak usia dini. Namun, terdapat beberapa kendala yang dihadapi oleh peserta didik yaitu, kurangnya pemahaman pentingnya pembentukkan karakter sejak usia dini dan kesulitan dalam belajar bahasa Inggris yang disebabkan oleh faktor lingkungan dan latar belakang orang tua. Oleh sebab itu, tim Pengabdian kepada Masyarakat $(\mathrm{PkM})$ kami terjun dan menawarkan solusi permasalahan berupa pengajaran menggunakan metode storytelling dengan menggunakan media buku cerita bergambar dan roll puppet berbahasa Inggris. Pesan moral yang diperoleh diantaranya menjadi lebih percaya diri, tidak pilih-pilih dalam berteman, tidak menghakimi teman, bersikap ramah, dan sebagainya. Pesan moral yang disampaikan melalui media ajar yang atraktif mampu memberikan pendidikan karakter pada anak dengan maksimal. Terlebih lagi, para peserta didik dapat belajar bahasa Inggris bersama-sama sekaligus meningkatkan pemahaman pesan moral dalam cerita dengan lebih menyenangkan. Pada intinya, Kegiatan PkM dengan storytelling ini bertujuan untuk membentuk karakter anak, memberikan pesan moral dan nasehat, menghibur, serta memotivasi anak untuk berbahasa Inggris.
\end{abstract}

Kata kunci: pendidikan karakter, pesan moral, storytelling 


\section{A. Pendahuluan}

Saat ini semua Negara di belahan dunia memasuki Revolusi Industri 4.0, semua orang harus mempersiapkan diri untuk mengikuti perkembangan zaman yang semakin pesat. Banyak tantangan yang harus kita hadapi yang mewajibkan kita untuk dapat menyerap perubahan yang terjadi dan tetap memegang teguh nilai-nilai luhur yang kita miliki. Permasalahan yang sedang menjadi perbincangan hangat saat ini salah satunya terjadi perubahan besar dalam kualitas kehidupan manusia. Kemajuan dalam segi ilmu pengetahuan dan teknologi yang sangat pesat saat ini justru membuat terjadinya kemunduran moral manusia. Seharusnya dengan peradaban manusia yang semakin maju harus seimbang dengan kemajuan moralnya.

Era globalisasi ini selain memberikan berbagai dampak positif bagi kemajuan bangsa yang tampak jelas dalam pesatnya perkembangan teknologi dan tuntutan untuk bisa menghasilkan SDM yang berkualitas agar memiliki daya saing global. Akan tetapi, juga menyisakan dampak negatif yang menjadi pekerjaan rumah bagi kita semua. Tanggung jawab orang tua dalam membesarkan dan mendidik anaknya semakin kompleks dan belum lagi kondisi orang tua saat ini banyak yang disibukkan dengan tugasnya dalam mencari nafkah sehingga waktu untuk membimbing anaknya mengalami banyak kendala. Mendidik anak agar menjadi pribadi yang berkarakter memang harus dimulai dari sejak dini. Dengan demikian, mereka akan memiliki kebiasaan baik yang sudah tertanam dari kecil. Karakter seorang anak harus dibentuk karena tidak muncul dengan sendirinya. Heraclitus menyebutkan bahwa "karakter merupakan takdir, sehingga karakter dapat membangun takdir seseorang" (Lickona, 2012). Jika kita memiliki karakter baik maka keberlangsungan kehidupan kita pun akan berjalan dengan baik dan mampu mengatasi segala permasalahan hidup dengan bijaksana. Oleh karena itu, peranan besar ada di tangan orang tua yang menjadi contoh utama si anak agar tumbuh menjadi pribadi yang berkarakter.

Peran lingkungan, pergaulan anak dan dunia pendidikan juga memberi poin penting untuk mendukung pendidikan karakter anak karena jika seorang anak hidup dalam lingkungan berkarakter baik, maka terbentuklah anak yang berkarakter baik pula, begitu juga sebaliknya. Oleh karena itu, dibutuhkan dukungan dari seluruh pihak yang terlibat mulai dari keluarga, sekolah, masyarakat, bahkan lembaga untuk membentuk karakter yang baik bagi anak (Zuchdi, Prasetya, Masruri. 2012). Menurut Permendiknas No.22 Tahun 2006 tentang Standar Isi untuk Satuan Pendidikan Tingkat Dasar dan Menengah, "pendidikan agama Islam diharapkan mampu menghasilkan manusia yang selalu berupaya menyempurnakan iman, takwa, dan berakhlak mulia, akhlak mulia mencakup etika, budi pekerti, atau moral sebagai perwujudan dari pendidikan”. TPA yang merupakan lembaga non formal sangat dibutuhkan untuk keperluan pendidikan yang menitik beratkan kepada ilmu agama. Dengan mengaji di TPA anak-anak akan dilatih bagaimana bersikap sesuai dengan nilai-nilai luhur yang berlaku, mereka secara langsung diberikan gambaran mana yang sesuai penerapan ilmu agama yang mereka pelajari.

Permasalahan inilah yang dihadapi masyarakat sekitar TPA Al-Ikhlas sejak tahun 2009. Bu Nurma, salah satu guru di TPA Al-Ikhlas, berinisiatif memberdayakan mushola milik Bapak Muslim untuk dijadikan tempat mengaji anak-anak sekitar 
mushola agar waktu luang mereka dapat diisi dengan kegiatan yang bermanfaat daripada anak-anak sibuk dengan gadget dan membentuk generasi yang berbudi luhur. Inisiatif tersebut mendapat tanggapan positif dari pemilik mushola dan masyarakat sekitar.

Sebelum ada TPA, anak-anak jika ingin mengaji terkendala dengan tempat yang jauh dan para orang tua memang khawatir dengan pergaulan anak sekarang jika tidak dibekali dengan kegiatan positif maka akan mudah terbawa pergaulan yang kurang tepat. Di samping itu, mayoritas para orang tua sibuk bekerja sebagai karyawan swasta dan tidak sanggup mengajari karena kendala ilmu serta tidak memahami metode pengajaran yang cukup. Jadi, dengan adanya donatur dan swadaya dari masyarakat maka berdirilah TPA Al-Ikhlas yang berlokasi di Parigi Baru, Pondok Aren, Tangerang Selatan yang dikepalai oleh Ibu Yuliana (istri dari Bapak Muslim).

TPA ini ingin turut serta berkontribusi dalam menyiapkan generasi muda yang mendalami ilmu agama dan mampu menjawab tantangan zaman dengan menguasai bahasa Inggris. Akan tetapi, permasalahannya belum adanya tenaga pendidik yang berkompeten mengajarkan bahasa Inggris kepada santrinya. Berdasarkan permasalahan tersebut, kami tim $\mathrm{PkM}$ menawarkan solusi untuk memberikan pengajaran bahasa Inggris menggunakan metode pembelajaran yang sesuai dan menarik. Metode pembelajaran merupakan langkah operasional dari strategi pembelajaran yang dipilih oleh pendidik guna mencapai tujuan pembelajaran (Sani, 2019). Metode pembelajaran yang dipilih dalam kegiatan ini adalah melalui cerita pendek atau storytelling yang disajikan dengan menarik sehingga memberikan pemahaman kepada anak akan manfaat pembentukkan karakter sejak usia dini.

Menurut (Aliyah, 2011) Storytelling terdiri dari story yang berarti cerita dan telling yang berarti pencerita. Penggabungan dua kata storytelling disebut juga bercerita cerita atau menceritakan cerita. Selain itu, Komisi Nasional Dewan Guru Bahasa Inggris dalam (Geisler, 1997) sepakat bahwa definisi storytelling yang lengkap adalah kegiatan mendongeng. Pada saat storytelling, ada beberapa faktor yang dapat menunjang berlangsungnya proses storytelling agar menjadi menarik untuk disimak (Asfandiyar, 2007), antara lain: kontak mata, mimik wajah, gerak tubuh, suara, kecepatan, dan alat peraga, sehingga para peserta didik dapat lebih fokus saat mendengarkan cerita. Selain itu, dengan adanya media pembelajaran buku cerita dan roll puppet berbahasa Inggris kreasi mahasiswa sebagai alat bantu ketika bercerita, maka akan mudah dalam menyampaikan pesan pembelajaran dan secara otomatis membuat kegiatan belajar-mengajar semakin menyenangkan. Analisis situasi bergantung pada masyarakat sasaran. Analisis dapat berupa uraian seluruh persoalan yang dihadapi masyarakat mitra dari aspek sosial, budaya, religi, kesehatan, mutu layanan atau kehidupan bermasyarakat. Dapat juga berupa potensi dan peluang usaha masyarakat mitra dari aspek sumber daya, produksi dan manajemen usaha. Dengan mengacu pada analisis situasi, tentukan permasalahan prioritas untuk masyarakat mitra yang bersifat spesifik, kongkret dan benar-benar merupakan permasalahan prioritas masyarakat mitra. 


\section{B. Pelaksanaan dan Metode}

Kegiatan Pengabdian kepada Masyarakat ini dilaksanakan di TPA Al-Ikhlas yang beralamat di Parigi Baru, Pondok Aren, Tangerang Selatan, Banten. PkM ini berlangsung selama 3 hari, yaitu tanggal 29, 30, dan 31 Maret 2021. Di TPA ini terdapat 2 sesi belajar, yaitu kelas siang hari pukul 14.00-16.00 dan kelas setelah Maghrib. Kelas yang dipilih pada PkM ini adalah kelas siang untuk anak TK dan SD yang berjumlah 65 dari keseluruhan 100 peserta didik. Serangkaian kegiatan PkM dilaksanakan dengan mengikuti protokol kesehatan. Para pendidik dan peserta didik terlebih dahulu mencuci tangan, memakai hand sanitizer, dan memakai masker yang telah dipersiapkan oleh tim PkM. Selain itu, secara teknis, para peserta didik dipisah menjadi 3 kelompok selama kegiatan, yang dibagi berdasarkan level usia, yaitu kelompok usia Taman Kanak-kanak, Sekolah Dasar kelas 1-3, dan Sekolah Dasar kelas 4-6.

Guna menarik minat belajar anak-anak dan dalam rangka pembentukan karakter anak, maka seperti yang telah disebutkan sebelumnya bahwa tim PKM kami melakukan pengajaran melalui metode storytelling dengan menggunakan media buku cerita dan roll puppet berbahasa Inggris kreasi mahasiswa sebagai alat bantu ketika bercerita. Dengan memenuhi kriteria tersebut, diharapkan pesan moral tentang pembentukan karakter diri yang ingin disampaikan melalui media buku cerita bergambar dan roll puppet mampu diperoleh secara maksimal. Adapun judul cerita yang disampaikan pada kegiatan $\mathrm{PkM}$ ini adalah sebagai berikut:

1. The Littlest Owl untuk usia Taman Kanak-Kanak.

2. Odil usia Sekolah Dasar kelas 1-3.

3. Landy the Lonely Hedgehog untuk usia Sekolah Dasar Kelas 4-6.

4. Mouse and the Lion untuk usia Sekolah Dasar kelas 4-6

Melalui storytelling yang ditampilkan, para peserta didik diharapkan mampu memahami isi cerita yang mengandung pesan moral terkait pengembangan karakter mereka, sehingga memiliki karakter diri yang semakin baik. Selain itu, di saat peserta didik mendengarkan cerita, mereka pun di latih untuk mengucapkan kosa kata berbahasa Inggris yang terdapat di dalam cerita tersebut dengan cara yang menyenangkan, sehingga para peserta didik secara langsung termotivasi untuk meningkatkan kemampuan bahasa Inggris yang mereka miliki.

Adapun metode yang digunakan dalam dalam kegiatan Pengabdian kepada Masyarakat ini adalah berupa penyampaian materi secara verbal mengenai pentingnya pendidikan karakter pada usia dini yang di sampaikan melalui storytelling. Lebih lanjut, metode TPR (Total Phisycal Response) digunakan dalam kegiatan ini. TPR merupakan salah satu metode pembelajaran bahasa yang menyelaraskan antara kordinasi perintah (command), ucapan (speech), dan gerak (action) dan berusaha untuk mengajarkan bahasa melalui aktivitas fisik (motor) (Richards \& Rodgers (2001). Detail metode pendekatan yang digunakan pada kegiatan PKM ini adalah sebagai berikut: 
1. Dengan melakukan interaksi langsung dengan peserta didik

Berinteraksi langsung dengan peserta didik mempermudah pendidik untuk mengarahkan mereka betapa pentingnya pembentukan karakter diri dalam kehidupan pribadi dan bermasyarakat. Serta membuka mata mereka betapa pentingnya penguasaan bahasa Inggris yang merupakan kebutuhan hidup di era saat ini untuk bekal masa depan mereka agar mampu bersaing di skala nasional dan internasional. Interaksi yang terjadi saat melakukan pendampingan dapat menciptakan komunikasi yang berkualitas dan mengotimalkan perkembangan anak. Secara psikologis, pendampingan dalam proses belajar akan membuat anak merasa aman, tidak sendiri, merasa diperhatikan dan dapat meningkatkan percaya diri mereka. Ini menjadi awal yang baik karena dapat mengembangkan kemampuan dan memotivasi belajar anak sehingga tujuan pembelajaran dapat dicapai. Seperti yang dikatakan oleh Hamzah (2012) bahwa motivasi belajar dibedakan atas dua kelompok, yakni motivasi intrinsik dan ekstrinsik, dan kegiatan belajar mengajar dalam PkM ini meningkatkan motivasi ekstrinsik anak untuk belajar melalui kegiatan yang menarik dan menciptakan lingkungan belajar yang kondusif. Sehingga, peserta didik lebih bersemangat dan merasa senang saat belajar, apalagi jika diimbangi dengan adanya penghargaan dari orang di sekitarnya yang mampu memahami kesulitan belajar dan kondisi anak.

\section{Pengajaran}

Pengajaran ialah suatu kegiatan yang dilakukan bersama oleh pendidik dan peserta didik. Pengajaran ini disusun secara sistematis oleh pendidik yang kemudian dilaksanakan sesuai dengan aturan dan teknik mengajar yang tepat. Di dalam pengajaran, pendidik juga membimbing dan memotivasi para peserta didik agar semangat belajar dalam memperoleh ilmu pengetahuan dan menguasai keahlian yang diperlukan. Dalam kegiatan pengabdian ini, pada pendidik memberikan pengajaran mengenai pesan moral dengan cara mendongeng atau storytelling untuk meningkatkan kesadaran akan pentingnya pembentukan karakter usia dini.

Selain storytelling, metode lain yang digunakan dalam pengajaran ini adalah melalui lagu. Lagu dianggap sebagai salah satu cara mengusir kebosanan. Melalui lagu, para peserta didik dapat lebih merasa senang dan nyaman karena lagu mengandung nada dan irama. Terlebih, lagu yang disajikan dalam kegiatan ini adalah lagu-lagu riang yang mampu mengingkatkan perasaan senang dan ceria. Tidak kalah penting, lagu yang dinyanyikan juga dapat membantu peserta didik untuk lebih mengingat kosakata yang diajarkan, sehingga kemampuan bahasa mereka meningkat.

\section{Mempraktekkan}

Metode praktik adalah metode pembelajaran untuk yang dipilih dalam kegiatan PkM ini untuk melatih peserta didik dengan tujuan untuk meningkatkan kemampuan peserta didik dalam menerapkan pengetahuan dan keterampilan yang sudah dipelajari. Pembentukan karakter diri sejak dini (character building) melalui storytelling dengan menggunakan media buku cerita bergambar dan roll puppet memiliki tujuan agar anak-anak lebih bersemangat dalam proses belajar. Tim Pengabdian kepada Masyarakat menanyakan kepada para peserta didik TPA Al-Ikhlas tentang isi cerita 
dan mempraktekkan dengan menceritakan ulang sesuai dengan pemahaman mereka agar mereka bisa mengenal karakter para tokoh dalam cerita serta menyebutkan pesan moral yang terdapat didalamnya. Hal tersebut perlu dilakukan mengingat tujuan PkM ini adalah untuk membentuk karakter anak yang dilakukan untuk mendidik mereka agar tidak memiliki karakter buruk dan termotivasi untuk menjadi pribadi yang berbudi luhur seperti oleh tokoh dalam cerita dan menghubungkan hal tersebut ke dalam kegiatan sehar-hari sebagai individu maupun bermasyarakat. Selain itu, ketika anak-anak menyampaikan pemahamannya, hal ini secara tidak langsung melatih mereka untuk lebih percaya diri tanpa merasa malu jika salah. Hal ini penting untuk dilakukan sebab sering kali anak tidak tertarik belajar bahasa Inggris karena merasa minder saat salah dalam pengucapan. Padahal proses belajar yang sesungguhnya harus melalui beberapa kesalahan. Selain itu, anak-anak juga diajarkan kosa kata yang berkaitan tentang gambar yang disajikan ketika cerita dibacakan.

Adapun rincian prosedur pelaksanaan kegiatan Pengabdian kepada Masyarakat adalah sebagai berikut:

1. Persiapan

2. Pembukaan Ketua Tim kegiatan Pengabdian Kepada Masyarakat membuka kegiatan.

3. Sambutan dari pengajar TPA dan Pembacaan do'a.

4. Brainstrorming dan sharing pengalaman antara dosen, mahasiswa, pengajar dan peserta didik.

5. Ice breaking.

6. Pembagian tim dan anak-anak menjadi 3 kelompok sesuai dengan level usia kelompok. Pembagian ini dilakukan untuk memaksimalkan pemahaman terhadap cerita dan menyesuaikan cerita yang akan disampaikan.

7. Pengenalan buku-buku cerita dan roll puppet.

8. Menyanyikan lagu-lagu anak.

9. Pembacaan cerita atau mendongeng (storytelling) menggunakan buku bergambar dan roll puppet yang sesuai dengan pokok bahasan.

10. Memahami cerita dengan meminta peserta didik untuk mengulang kembali isi cerita memalui metode "recall" dengan menggunakan pertanyaan $5 \mathrm{~W} 1 \mathrm{H}$ mengenai tokoh dan isi cerita.

11. Menanyakan cerita atau mendiskusikan kosakata.

12. Mendiskusikan pesan atau nilai moral dari cerita.

13. Memberikan model kepada anak-anak dan memberikan contoh.

14. Tanya jawab dan diskusi

15. Penutup dan doa.

\section{Hasil dan Pembahasan}

Pengabdian kepada Masyakat dilakukan selama tiga hari di Taman Pendidikan Al-Qur'an Al-Ikhlas, desa Parigi Baru-Pondok Aren. Dalam PkM kali ini, para peserta yang terdiri dari anak-anak usia Pendidikan Dasar Usia Dini dan sekolah dasar dibagi dalam tiga kelompok yang terdiri dari lima belas sampai dua puluh anak. Pembagian kelompok dilakukan berdasarkan kelas mereka. Hal ini dilakukan untuk memudahkan 
penyampaian materi dan juga kesesuaian cerita yang akan disampaikan. Selama kegiatan berlangsung, penulis melakukan interaksi dengan para peserta didik, pengajaran dan mempraktekan. Hal ini dilakukan untuk memperolehkan penemuan yang diharapkan. Dengan menerapkan metode tersebut selama tiga hari, terdapat beberapa penemuan yang didapat penulis, diantaranya dapat dijabarkan sebagai berikut:

1. Memahami isi bacaan dan pesan moral yang terdapat dalam cerita

Buku cerita dan roll puppet digunakan sebagai media untuk menyampaikan cerita kepada para peserta. Media yang menarik membuat anak-anak antusias mendengarkan cerita. Untuk memudahkan pemahaman para peserta terhadap isi cerita, cerita dibacakan dalam bahasa Inggris kemudian diikuti artinya dalam Bahasa Indonesia.

Menurut Asfandiyar (2007), ada beberapa faktor penunjang dalam penyampaian storytelling agar tidak membosankan, antara lain: kontak mata, gerak tubuh, suara, kecepatan, mimik wajah, dan alat peraga. Kontak mata dilakukan bukan hanya saat menyampaikan cerita, namun juga pada saat mengeja, ataupun saat memberikan instruksi sederhana. Hal ini dilakukan agar para peserta didik tidak teralihkan perhatiannya karena merasa bosan dan jenuh. Mimik wajah yang diekspresikan hendaklah sesuai dengan isi cerita. Misalnya ketika isi cerita tentang sesuatu yang menyedihkan, maka penulis juga mengekspresikan mimik sedih. Begitu pula Ketika bercerita tentang si tikus yang ketakutan, maka mimik wajah yang ditampilkan adalah mimik wajah seseorang yang ketakutan. Hal ini dilakukan agar membantu para peserta memahami isi cerita. Gerak tubuh yang dilakukan, juga sangat membantu dalam penyampaian cerita agar lebih meningkatkan pemahaman peserta akan isi cerita. Suara dan kecepatan pada saat penyampain cerita juga faktor yang menjadi pertimbangan penting. Kecepatan bercerita di depan peserta usia sekolah dasar tentu akan berbeda ketika bercerita kepada peserta yang berada di usia Pendidikan Anak Usia Dini. Alat peraga buku cerita dan roll puppet yang menarik dan penuh warna menjadi daya tarik tersendiri bagi para peserta didik. Mereka sangat senang melihat karekter-karakter yang dapat dilepas dan dipasang seiring dengan jalannya cerita.

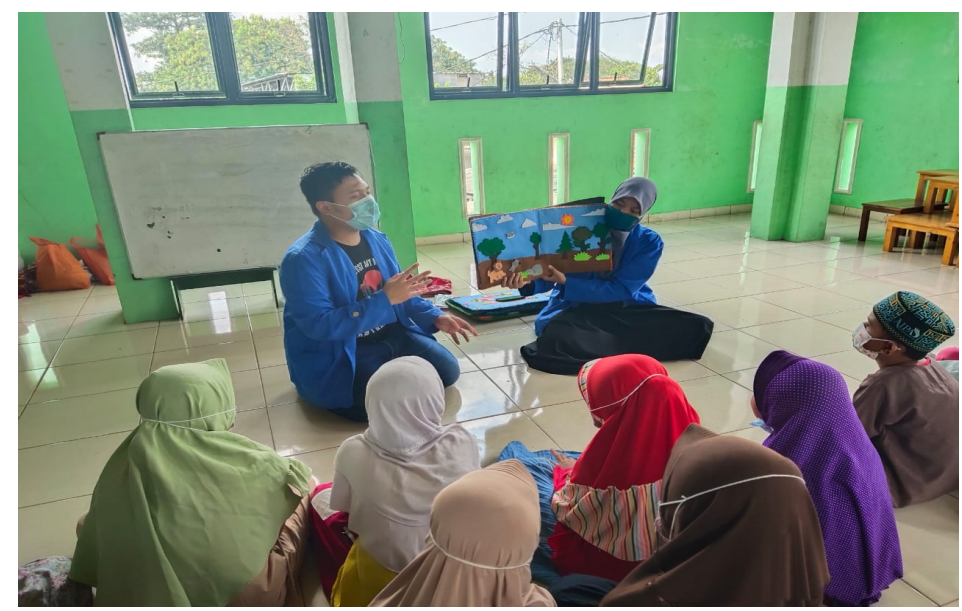

$\overline{\text { ACITYA BHAKTI, Volume } 1 \text { Nomor 2, Agustus 2021 }}$ 
Gambar 1. Penyampaian cerita Mouse and the Lion pada kelompok 1

Pada gambar diatas, penyampaian cerita Mouse and the Lion dilakukan dengan menggunakan roll puppet pada kelompok satu, yaitu peserta didik usia sekolah dasar kelas empat sampai kelas enam. Para peserta didik duduk dengan tengan mendengarkan cerita. Melalui cerita Mouse and the Lion tersebut, para peserta didik diajarkan bahwa apapun yang kita lakukan, entah itu perbuatan baik ataupun buruk, maka kita jugalah yang akan menuai perbuatan tersebut.

Setelah mendengarkan cerita Mouse and the Lion, para peserta didik di kelompok ini melakukan tanya jawab dan kemudian berlanjut ke judul berikutnya, yaitu Landy the Lonely Hedgehog. Landy the Lonely Hedgehog adalah cerita seekor landak yang selalu sendirian karena tidak ada yang mau berteman dengannya. Landy mempunyai duri di punggungnya yang dapat melukai yang lain. Suatu hari Mr. Turtle sang kurakura mengundang Landy untuk datang ke pesta ulang tahunnya, dan Mr. Turle berjanji akan berteman dengan Landy. Landy pun sangat bahagia. Ternyata, Landy yang berduri tajam di tubuhnya memiliki hati yang baik. Cerita ini mengajarkan bahwa kita tidak boleh menilai orang lain dari penampilannya seperti Landy yang memiliki duri namun baik hati. Selain itu, cerita ini juga mengajarkan untuk selalu berbuat baik kepada orang lain, untuk menjadi diri sendiri, dan untuk menjadi pemberani.

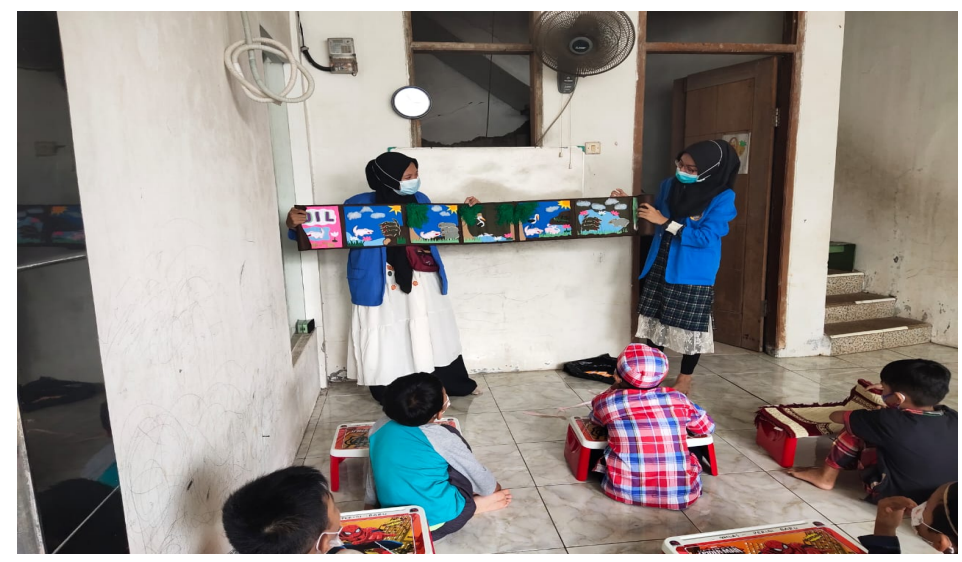

Gambar 2. Penyampaian cerita Odil

Odil adalah cerita yang disampaikan pada kelompok dua dengan peserta usia sekolah dasar kelas satu sampai tiga. Odil yang bercerita tentang seekor buaya bernama Odil yang sering diejek oleh teman-temannya karena kulitnya yang berwarna putih dan berbeda dari teman-teman yang lain. Hal ini membuatnya menjadi tidak percaya diri dan tidak memiliki kawan. Dari cerita ini, para peserta diajarkan agar tidak mengejek siapapun walaupun dia berbeda dari kita sekalipun. Odil juga mengajarkan agar kita bisa lebih percaya diri dan mencintai diri kita sendiri. 


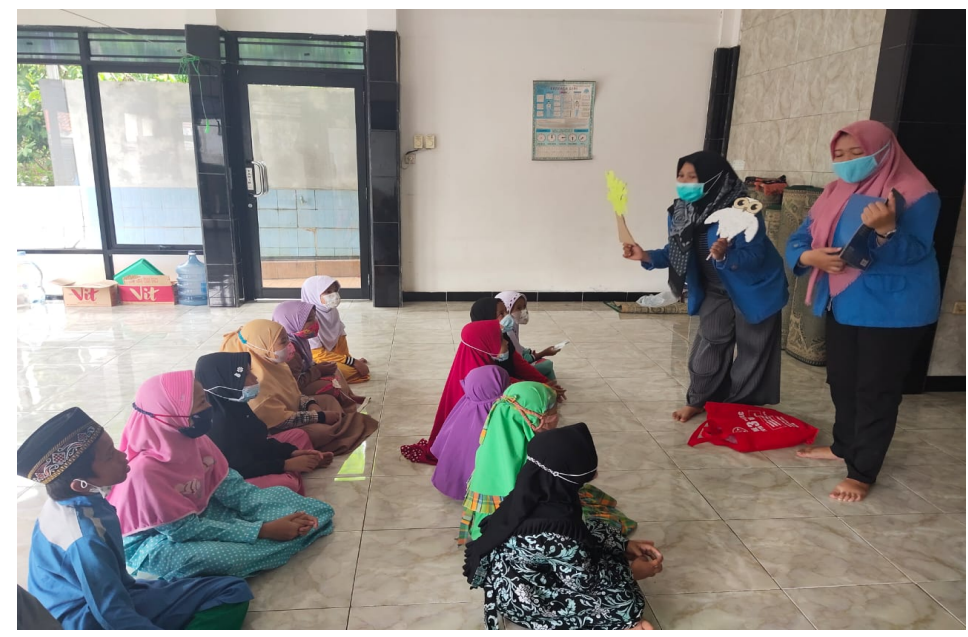

Gambar 3. Penyampaian cerita The Littlest Owl

The littlest $O w l$ adalah cerita yang dipilih untuk disampaikan pada kelompok tiga dengan peserta anak usia dini. The Littlest $O w 1$ mengajarkan agar kita tidak mudah berputus asa akan kondisi kita dan tetap saling menjaga antar sesama anggota keluarga apapun yang terjadi.

Penyampaian storytelling yang menarik dengan menggunakan media buku cerita dan roll puppet ini menjadikan anak-anak peserta didik sangat menikmatinya. Mereka antusias mendengarkan cerita dari awal sampai akhir. Sehingga ketika mereka diminta untuk bercerita tentang isi cerita yang telah mereka dengar, mereka dengan senang hati menceritaknnya dengan bahasa mereka sendiri. Ini menunjukan para peserta memahami isi cerita dengan baik sehingga mereka mampu mengulangi cerita tersebut. Begitu pula ketika para peserta ini diminta untuk menyebutkan tokoh mana saja yang perilakunya boleh ditiru dan mana yang tidak boleh ditiru, mereka dapat menyebutkannya dengan benar bahkan disertai alasannya. Hal ini menunjukan bahwa metode storytelling dengan media roll puppet adalah media yang tepat dalam penyampaian pesan moral terhadap anak, terutama anak usia sekolah dasar dan PAUD.

2. Menambah penguasaan kosa kata bahasa Inggris

Anak-anak adalah peniru yang ulung. Mereka mampu menirukan apa yang mereka lihat dan mereka dengar dengan baik sehingga menjadikan metode praktik salah satu metode yang tepat dalam pengajaran bahasa Inggris. Karena bukan bahasa asli dan bahasa keseharian mereka, maka diperlukan praktik secara kontinyu untuk membiasakan mereka mendengar dan mengucapkan kata- kata dalam bahasa Inggris. Dengan praktik terbimbing, penulis mencontohkan bagaimana cara pengucapan kosa 
kata dalam bahasa Inggris, seperti bagaimana cara memperkenalkan diri, mengucapkan kata sifat dari para tokoh yang terdapat dalam cerita, kata kerja yang digunakan dalam cerita, dan nama-nama binatang yang menjadi tokoh dalam cerita. Sedangkan melalui praktik mandiri, para peserta diminta untuk menirukan cara memperkenalkan diri dalam bahasa Inggris, dan pengucapan kata berbahasa Inggris secara bergantian. Hal ini dilakukan agar para peserta bukan hanya mendengarkan apa yang diucapkan, tetepi mereka juga mampu untuk mengucapkan kata-kata dalam bahasa Inggris dengan baik dan benar. Jika para peserta didik melakukan kesalahan dalam pengucapan bahasa Inggis, maka penulis mengoreksinya dan mencontohkan kembali bagaimana pengucapan yang benar.

Selain storytelling, menyanyi merupakan media yang juga digunakan dalam Pengabdian kepada Masyarakat kali ini. Menyanyi dilakukan sebagai pembuka sebelum penyajian cerita. Hal ini bertujuan untuk mencairkan suasana, mendapatkan perhatian penuh dari para peserta, serta menciptakan suasana yang ceria. Melalui lagu ini pula, para peserta diajak untuk menambah beberapa kosa kata bahasa Inggris yang baru yang terdapat dalam lagu tersebut.

Berdasarkan pengamatan, penggunaan metode storytelling dan media roll puppet dinyatakan cukup efektif dalam meningkatkan pemahaman pesan moral, terutama bagi anak usia dini dan sekolah dasar. Hal ini dikarenakan beberapa hal, diantaranya adalah penggunaan media buku cerita dan roll puppet. Bentuk yang lucu dan warna yang terdapat dalam roll puppet menarik perhatian anak. Hal ini membuat anak betah duduk memdengarkan dan memperhatikan cerita. Kedua, intonasi dalam penyampaian cerita. Anak bukan hanya disuguhi dengan visual yang bagus, tapi juga didukung oleh audio meraka melalui intonasi dan kecepatan yang bervariasi dalam penyampaian cerita. Ketiga, mimik wajah dan gerak tubuh yang mendukung isi cerita, sehingga anak lebih mudah memahami isi cerita. Keempat, cerita yang diangkat sederhana dan mudah dipahami. Bahasa yang sederhana memudahkan anak-anak untuk memahami isi dan pesan moral yang ada didalamnya. Tokoh-tokoh hewan yang imut dan menggemaskan dalam cerita membuat anak-anak lebih tertarik.

Namun demikian, Pengabdian kepada Masyarakat ini bukan tanpa kendala. Pemilihan cerita yang sesuai, penyampaian yang menyenangkan dan tidak membosankan, serta mempertahankan kosentrasi peserta terhadap cerita merupakan beberapa hambatan yang kami hadapi. Pemilihan cerita dan cara penyampaian merupakan hal yang mendasar yang harus menjadi pertimbangan dalam metode storytelling ini. Cerita yang disampaikan haruslah sesuai dengan usia peserta serta didukung oleh penyampaian yang menyenangkan. Bagaimana mimik wajah pencerita saat sedih, marah, malu, gembira dan perasaan-perasaan lain sehingga dapat dilihat dengan jelas oleh peserta. Mempertahankan kosentrasi peserta agar hanya terfokus pada apa yang disampaikan juga merupakan tantangan terbesar dalam PkM dengan metode storytelling. Dengan banyaknya peserta dan kesemuanya anak-anak, membuat kosentrasi mereka sering teralihkan bahkan oleh hal-hal kecil seperti suara dari 
kelomok lain ataupun suara-suara yang berasal dari sekeliling area TPA Al-Ihlas, seperti suara abang penjual makanan ataupun musik..

\section{Penutup}

\section{Simpulan}

Pengabdian kepada Masyarakat dilakukan selama tiga hari di Taman Pendidikan Al-Qur'an Al-Ikhlas dengan menggunaan metode storytelling dan media roll puppet sangat diminati peserta didik terlihat dari antusias yang sangat tinggi untuk mempelajari kosa kata bahasa Inggis. Setelah kegiatan PkM ini, diharapkan peserta didik semakin meningkat penguasaan kosa kata bahasa Inggris yang dapat digunakan dalam aktivitasnya sehari-hari. Selain itu, mereka mendapatkan pesan moral yang mudah dipahami karena disampaikan pengajar dengan media pembelajaran yang menyenangkan sehingga peserta didik mendapatkan ilmu baru yang tidak monoton.

\section{Saran}

Kegiatan Pengabdian kepada Masyarakat di tempat tersebut dapat dilakukan secara berkesinambungan agar dapat memberikan konstribusi dalam mewujudkan cita-cita dalam membangun peserta didik yang memiliki karakter berkebangsaan yang tinggi dan juga memiliki kemampuan penguasaan bahasa Inggris sehingga kita bersama mempersiapkan generasi yang unggul. Selain itu, peran serta orang tua dan lingkungan juga harus bersinergi bersama dalam membekali anak-anak untuk mengisi keseharian mereka dengan kegiatan yang positif sebagai bekal hidupnya menghadapi perkembangan zaman yang semakin ketat.

\section{Ucapan Terima Kasih}

Ucapan terima kasih disampaikan Universitas Pamulang, LPPM, dan Fakultas Sastra Inggris yang telah memberikan kesempatan dan dukungan untuk melaksanakan kegiatan PkM ini. Serta kepada pemilik, pengelola, dan para pengajar TPA Al-Ikhlas Parigi Baru-Pondok Aren yang telah mendukung dan membantu demi terlaksananya kegiatan PkM ini.

\section{DAFTAR PUSTAKA}

Aliyah, S. (2011). Kajian teori metode storytelling dengan media anggung boneka untuk meningkatkan kemampuan menyimak dan berbicara anak usia dini: studi eksperimen quasi di TK negeri pembina kabupaten Majalengka [Unpublished thesis]. Universitas Pendidikan Indonesia.

Asfandiyar, A. Y. (2007). Cara pintar mendongeng. Mizan.

Geisler, H. (1997). Strorytelling professionally: the nuts and bolts of a working performer. Libraries Unlimited, Inc. 
Hamzah B. Uno. (2012). Teori motivasi dan pengukurannya: analisis di bidang pendidikan. Jakarta: Bumi Aksara.

Lickona, T. (2012). Character matters. Bumi Aksara.

Permendiknas No.22 Tahun 2006, tentang standar isi untuk satuan pendidikan tingkat dasar dan menengah.

Richard, J., \& Rodgers, T. (2001). Approaches and methods in language. Cambridge University Press.

Sani, R.A. (2019). Inovasi pembelajaran. Bumi Aksara.

Zuchdi, et al. (2012). Model pendidikan karakter terintegrasi dalam pembelajaran dan pengembangan kultur sekolah. UNY Press. 